\title{
Getting to Darwin: Obstacles to Accepting Evolution by Natural Selection
}

\author{
Paul Thagard $\cdot$ Scott Findlay
}

(C) Springer Science+Business Media B.V. 2009

\begin{abstract}
Darwin's theory of evolution by natural selection is central to modern biology, but is resisted by many people. This paper discusses the major psychological obstacles to accepting Darwin's theory. Cognitive obstacles to adopting evolution by natural selection include conceptual difficulties, methodological issues, and coherence problems that derive from the intuitiveness of alternative theories. The main emotional obstacles to accepting evolution are its apparent conflict with valued beliefs about God, souls, and morality. We draw on the philosophy of science and on a psychological theory of cognitive and emotional belief revision to make suggestions about what can be done to improve acceptance of Darwinian ideas.
\end{abstract}

\section{Introduction}

Darwin's theory of evolution by natural selection is widely recognized by scientists as the cornerstone of modern biology, but many people, especially in the United States, remain skeptical (Miller et al. 2006). According to a recent poll in Canada's oil-rich province of Alberta, more people there believe that humans were created by God within the last 10,000 years than that humans evolved from less advanced life forms over millions of years (Breakenridge 2008). Science educators in several countries have reported serious problems in enabling students to understand and accept evolution by natural selection (e.g. Anderson 2007; Blackwell et al. 2003; Deniz et al. 2008; Evans 2008; Hokayem and BouJaoude 2008; Sinatra et al. 2003).

At first glance, adoption of Darwin's theory should be straightforward. First, people can be instructed in basic ideas about how genetic variation and competition among individual organisms produce natural selection for characteristics that increase survival and reproduction in particular environments. Second, they can be led to see how natural selection has produced many kinds of evolutionary change, from the development of well-functioning organs to the occurrence in bacteria of resistance to antibiotics. Third, from

P. Thagard $(\bowtie) \cdot$ S. Findlay

Philosophy Department, University of Waterloo, Waterloo, ON N2L 3G1, Canada

e-mail: pthagard@uwaterloo.ca 
presentation of the many kinds of evidence that have been explained using evolution by natural selection, people should be able to appreciate that Darwin's theory has far greater explanatory power than any available alternatives and therefore should be accepted.

Unfortunately, for science students and the population in general, there are major psychological obstacles to accepting Darwin's theory. Cognitive obstacles to adopting evolution by natural selection include conceptual difficulties, methodological issues, and coherence problems that derive from the intuitiveness of alternative theories. The main emotional obstacles to accepting evolution are its apparent conflict with valued beliefs about God, souls, and morality. Using a theory of cognitive and emotional belief revision, we will make suggestions about what can be done to improve acceptance of Darwinian ideas.

\section{Cognitive Obstacles}

Darwin's theory of evolution by natural selection should be accepted by everyone because it provides a far better explanation of a wide range of biological phenomena than available alternatives. Resistance to the theory is partly the result of emotional factors that we will discuss later. But first we will review cognitive factors that make it difficult for many people to understand and accept Darwin. Understanding his theory requires grasping its central concepts such as natural selection and appreciating how evolution by natural selection can explain many biological phenomena such as speciation. Accepting the theory (in philosophical terminology) would be the further step of judging it to be true.

\subsection{Conceptual Difficulties}

At first glance, the concepts required to understand evolution by natural selection should not be particularly hard to grasp. Such concepts as evolutionary change, genetic variation, struggle for existence, and natural selection can all be described qualitatively, without the mathematical complexities that impede understanding of major theories in physics such as relativity and quantum mechanics. But Darwin's theory concerns biological processes that are statistical and emergent in ways that do not fit well with common sense explanations.

The two kinds of explanations that people are most familiar with are intentional ones and simple mechanical ones. Intentional explanations are familiar from social experience, for example when individuals' decisions about careers are explained in terms of their beliefs and desires. Everyday mechanical explanations depend on causal relations that can be captured by straightforward if-then rules, such as if a bicycle's pedals turn, then its crank, chain, and wheels also turn. Thus the operation and occasional breakdowns of bicycles are amenable to simple explanations in terms of the parts and interactions of its pedals, crank, chain, and wheels.

In contrast, evolutionary explanations are inherently statistical, involving probabilistic changes in genes and species. They require what the eminent evolutionary biologist Ernst Mayr (1982) called population thinking, which he contrasted with more natural typological thinking in terms of essences. Such statistical thinking is not natural to human cognition, as probability theory and the theory of statistical inference have only been invented in recent centuries (Hacking 1975). Few students in high schools and universities are exposed to statistical thinking, so it is not surprising that people have difficulty thinking of biological species in statistical terms. Sophisticated probabilistic thinking in science only developed in the late nineteenth century in the field of statistical mechanics, which inspired twentieth- 
century work on population genetics. There is psychological research showing that conceptualization of species in terms of essences (inner natures) is an impediment to understanding natural selection (Shtulman 2006; Shtulman and Schulz 2008). Even when students accept evolution, they may continue to believe that it operates on a species' essence rather than on its members.

In addition to being inherently statistical, evolutionary explanations require appreciation of emergent processes, ones in which large effects result from small operations that are qualitatively different. In a simple mechanism such as a bicycle, the motion of the whole system can easily be seen to result from the motions of the parts. An emergent property is one that belongs to a system but not to any of the system's parts (Bunge 2003). Such properties are ubiquitous in the natural world, at many levels including molecules, cells, organs, organisms, and societies. To take a very simple example, molecules of sodium chloride (table salt) have properties such as stimulation of taste buds that are different from and hard to predict from the properties of the sodium and chlorine atoms that constitute them. An emergent process is one that produces emergent properties. The evolution of a new species is an emergent process arising from small genetic changes in a large number of individuals until eventually there exists a population of organisms no longer capable of interbreeding with members of previous species. Students need to understand how natural selection can lead not only to gradual changes within a population, but also to speciationthe emergence of a qualitatively different kind of organism.

Chi $(2005,2008)$ has reviewed the learning difficulties encountered by students who need to understand emergent processes in physics. Students naturally understand entities and their properties, such as animals that have sizes and colors. More difficult is appreciating processes that occur over time, but these are not so difficult as long as they are direct, where each change has an identifiable causal agent. In emergent processes however, changes come about because of many small interactions, for example the diffusion of oxygen from the lungs to the blood vessels and migrating geese flying in a V-formation. Students' failure to understand how species can emerge without direction is part of widespread inability to understand emergent processes. Grasping speciation as the result of evolution by natural selection is made even more difficult by the fact that it occurs over a much larger time scale-usually thousands or millions of years - than students have previously encountered. Because of the relative security of modern cultures, the evolutionary pressures that produced human speciation are no longer evident.

Genetic changes are slow and statistical, in contrast to simple mechanical or intentional changes that are fast and direct. Students are naturally drawn to Lamarckian explanations in terms of the heritability of acquired characteristics, which is similar to the rapid, directed changes that take place in people's personal lives and cultural developments. Darwin lacked a good theory of how variation in populations can occur and be transmitted to future generations, a gap filled in the twentieth century by genetics. But most students are not well equipped to appreciate the non-directed nature of genetic mutation or the statistical nature of population genetics. Students also have a natural inclination toward purpose-based teleological explanations akin to familiar intentional explanations (Kampourakis and Zogza 2008).

Historically and currently, one of the greatest obstacles to acceptance of evolution is the claim that human thought is a product of it. Alfred Wallace, who discovered natural selection independently of Darwin, was never able to accept that it applied to minds, which he thought had an irreducible spirituality. Students today find that the most implausible aspect of Darwin's theory is the suggestion that it could provide a way of accounting for the operations of human minds (Ranney and Thanukos 2009). Here students have a double 
difficulty: not only is evolution an emergent process on the Darwinian account, but thinking is also an emergent process on the account currently being developed in neuroscience. Thoughts are the result of the interactions of billions of neurons, each of which fires as the result of the interactions of thousands of genes, proteins, and other molecules. To believe that human thinking evolved by natural selection, a student has to be able to grasp several levels of emergent processes, including:

1. How evolution by natural selection could have produced the human brain.

2. How interactions among neurons and neurochemicals could produce human thought.

Thus the human mind is an emergent process resulting from an emergent process! So it is small wonder that students and ordinary people, not to mention many contemporary philosophers, have great difficulty imagining how mind could be the result of brain structures arising from natural selection.

Contrary to common sense psychology, we know from cognitive psychology and neuroscience that thinking is largely an unconscious process. People may think they understand their own minds through the conscious process of introspection, but cognitive research has shown that self-observation provides a very limited and sometimes misleading source of information about how the mind works. In particular, conscious experience tells us little about the evolved biological processes that make consciousness possible. Thagard and Aubie (2008) offer a neurocomputational model of emotional consciousness that explains how many interacting brain areas can generate such emotions as happiness. But many people find it hard to conceive that conscious experience can be the result of biological processes.

\subsection{Methodological Difficulties}

Even if students manage to understand the complex process of evolution by natural selection, the question still arises how or why they should come to believe it. Within philosophy of science, there are contradictory accounts of what would be involved in accepting Darwin's theory. Here are just four:

1. A follower of the philosopher of science Karl Popper (1959) could say that students should not accept Darwin's theory at all, for two reasons. First, no one should ever accept a scientific theory, since scientific method consists only of making bold conjectures and trying to falsify them. Second, evolution by natural selection is not a scientific theory, since it is not falsifiable. Popper (1978) eventually retracted the second claim, but in any case there are many logical and historical reasons why Popper's falsificationism should not be taken as the standard of scientific method (Sober 2008; Thagard 1988).

2. A follower of the historian of science Thomas Kuhn (1970) could say that Darwin's views are a new paradigm that is incommensurable with the old, creationist paradigm, so there is no objective way of choosing one over the other. In his later writings, Kuhn backed away from such a subjectivist interpretation of his earlier views, and Thagard (1992) argued that radical incommensurability and irrationality are not features of scientific revolutions.

3. Bayesians say that belief revision should be in accord with probability theory, in particular with Bayes' rule which says that the probability of a hypothesis given evidence is equal to the result of multiplying the prior probability of the hypothesis times the probability of the evidence given the hypothesis, all divided by the 
probability of the evidence: $P(H / E)=P(H) * P(E / H) / P(E)$. As a theorem of probability theory, this rule is unassailable, but its application to actual cases of reasoning is highly problematic (Thagard 2000). What is the correct interpretation of probability here, and how does one come up with numbers such as the probability of the evidence given Darwin's theory? Sober (2008) provides a sophisticated probabilistic discussion of the evidence for natural selection, but it would be hard to apply in science education.

4. Thagard $(1988,1992)$ argued that Darwin's theory has been and should be accepted because of its explanatory coherence, which takes into account how it compares with alternative theories such as creationism according to the range of facts explained, simplicity, and analogies such as Darwin's comparison of natural selection tof artificial breeding. This account fits very well with Darwin's own argument and with widespread inferential practice (Kitcher 1981).

If the explanatory coherence account of scientific justification is correct, it should be appropriate to try to convince students of Darwin's theory using inference to the best explanation: lay out the evidence and alternative explanations, and determine what competing hypotheses explain the evidence best. Unfortunately, attempts to use explanatory coherence for educational purposes revealed pedagogic problems (Schank and Ranney 1992). Philosophers, scientists, and science educators may take it for granted what hypotheses and evidence are, but these concepts are by no means clear to average students. Hence there needs to be an elemental exposition of scientific method starting with the clarification of the nature of evidence, explanations, hypotheses, and theories (see Thagard 2010, 2009). Only then can students have a chance of grasping that they should accept Darwin's theory, not just because it is in the textbook or class lectures, but because it is a powerful explanatory theory. Students need to learn not just what to believe, but how to believe for the right scientific reasons. Then getting to Darwin presupposes the methodological leap of getting to science first, a historically and psychologically difficult process. After all, the systematic evaluation of competing hypotheses with respect to experimental and observational evidence only began to be practiced and understood in the sixteenth and seventeenth centuries, and most students hit high school and even university with minimal exposure to it.

\subsection{Coherence Difficulties}

Suppose that students overcome conceptual difficulties and understand Darwin's theory, and suppose that they overcome methodological difficulties and grasp the importance of inferring the best explanation of all the evidence. It still does not follow that they will become avid Darwinians, if they see evolution as incoherent with alternative explanations that they grew up with. Christian, Muslim, and other religious traditions do not mention evolution by natural selection, and offer a strikingly different account of the origin of species: divine creation. In Darwin's time, creation was the dominant view even in scientific circles, and Darwin constructed On the Origin of Species explicitly as an alternative to creationist explanations. According to the Bible, God produced light, sky, water, land, vegetation, and animals over a few days, which is a very different story from the biological view that species on earth evolved over the course of billions of years. Students who grow up with the religious story will need to either reject it or revise it dramatically before they become capable of accepting evolutionary explanations of the origins of species. Preson and Epley (2009) present evidence that the conflict between religious and scientific 
explanations can occur automatically, such that increasing the perceived value of one decreases the evaluation of the other. Later we will discuss various pedagogical strategies for dealing with the incoherence that students face between biological and theoretical explanations of how Homo sapiens and other species came to be.

The Darwinian, biological view of human origins is incoherent not only with religious views, but also with common psychological views that fit very well with religious accounts. According to many religious traditions, God gave people souls that enable them to make free decisions and to survive the death of their bodies. This doctrine contradicts the biological view that thought results from processes in brains that became increasingly complex through hundreds of millions of years of evolution. In order to accept the application of Darwin's theory to the human species, including its mental faculties, students may need to replace the religion-derived explanatory account of minds as souls with the relatively recent view of minds as brains. At the very least, students will need to revise their religious and psychological beliefs, as some scientists have, to allow for compatibility between religion and biology.

In sum, there are three major cognitive obstacles to accepting Darwin's theory of evolution by natural selection: understanding the theory in the face of conceptual difficulties, grasping the nature of scientific evaluation of evidence, and dealing with incoherence between biological explanations and much more familiar explanations of life and mind derived from religion and common sense psychology. These alternative explanations are not only familiar, but are also highly emotionally attractive, so that there are serious emotional obstacles to getting to Darwin.

\section{Emotional Obstacles}

Rationally, people are supposed to form their beliefs on the basis of evidence, not according to what they want to be true. But it would be naïve to ignore the fact that people often shape their beliefs in part by their goals, a process that psychologists call motivated inference (Kunda 1990, 1999). For example, people may overestimate their chances of winning a lottery or underestimate their chances of getting a disease because of what they want to happen. Thagard $(2003,2006)$ showed how such motivated inferences can arise from a process of emotional coherence, in which beliefs arise through a combination of explanatory coherence (as described above) and emotional influences: people are inclined to accept beliefs that fit with their goals, and to reject beliefs that conflict with their goals.

The problem that many people have with accepting Darwin's theory is not just that it conflicts with their existing religious and psychological beliefs, but that it conflicts with some of their deepest personal motivations. People do not just think that evolution by natural selection is false: they want it to be false. Even people who believe in evolution may admit that they would prefer it to be false (Brem et al. 2003)!

Let us try to identify the key motivations that generate emotional obstacles to accepting evolution by natural selection. There are many appealing aspects of the religious-psychological perspective that God created the world and human souls. First, this perspective carries the comforting picture, found in Christianity and some other religions, of a loving and all-powerful God. Many people receive from this picture great reassurance that the many problems that life presents (disappointment, disease, death) are transitory parts of a beneficent, divine plan. Second, this divine plan potentially includes everlasting happiness, which requires the existence of an immortal soul that is immune from the threat of bodily death. Third, within our lifetimes, people are not completely constrained by the kinds of 
physical and biological forces that generated evolution, but rather operate by free will. Not only is free will supported by our subjective experience of having genuine choices to make, it also fits with our preferred view of ourselves and others as responsible agents. A major reason why people recoil from Darwinian approaches to biology and psychology is that they see it as rendering their lives meaningless, devoid of the spirituality and morality that make life worth living.

So students may not just see themselves as facing a cognitive choice between two competing theories of the origin of species, but as facing an emotional choice between two competing systems of values. On the one hand, there is the familiar, reassuring religious picture that includes a caring God, immortality, free will, moral responsibility, and meaningful lives. On the other land, there is the gloomy scientific picture of humans as specks in the vast universe, irrevocably doomed to die after a brief life devoid of freedom, morality, and purpose. So it is small wonder that students are highly motivated to look skeptically at the vast evidence for Darwin's theory, and eager to seize on the feeble arguments of proponents of creationism and intelligent design. Who would want to accept Darwin if doing so would suck all meaning from life? (It does not have to: see the discussion below and Thagard 2010).

Resistance to evolution by natural selection can also take on a political dimension. Acceptance of evolution varies wildly between different countries, partly as a result of political pressures. In the United States, for example, skepticism about Darwin is associated with highly conservative political views as well as religious fundamentalism. Politics also figure in other scientific controversies, such as whether the main cause of global warming is human increase in carbon emissions. Resistance to claims that people are responsible for climate change tends to come from politicians sympathetic to the oil industry and antagonistic to government intervention (Thagard and Findlay 2009). Hence change in scientific beliefs can encroach on political values as well as on personal motivations.

In the next section, we will address how science educators might draw on philosophy and psychology to allay students' fears about the psychological devastation that appreciating Darwin might bring. Our purpose here is to emphasize that resistance to Darwinian ideas is not just a cognitive matter of comprehension, scientific inference, and belief revision, but also an emotional matter of reconciling conflicting views of what is valuable about life. When cognitive and emotional obstacles combine and interact, it is not surprising that evolution by natural selection meets enormous resistance, as it did in the nineteenth century and continues to do so today. Conceptual change concerning topics that matter to people is often an emotional process as well as a cognitive one (see also Thagard 2008, 2009; Thagard and Findlay 2009). So what is the science educator to do?

\section{Implications for Science Education}

Teachers who want their students to understand and accept Darwin's theory of evolution might pursue one of three pedagogic strategies: detachment, reconciliation, or confrontation. By detachment we mean that the presentation and discussion of evolution and other biological theories can be discussed with no mention of the coherence difficulties and emotional obstacles that arise from religious issues. Science is simply detached from religion, in line with the American doctrine of separation of church and state.

By reconciliation we mean that possible conflicts between science and religion are mentioned, but they are resolved by finding compatibilities between scientific and religious 
views. Several avenues of reconciliation are possible, including a postmodernist assertion that science and religion are just different modes of discourse, a separatist assertion that science and religion are not incompatible because they operate in different realms, and a quasi-scientific advocacy of a view called theistic evolution, according to which God is the designer of the evolutionary process.

Finally, at the most extreme, there is the strategy of confrontation, in which scientific views are presented as contradictory with and superior to the religious views that provide the cognitive and emotional motivations for rejection of evolution by natural selection. Which of these strategies is the best for different kinds of science education depends on a host of philosophical, scientific, psychological, and political factors.

Politically, by far the easiest pedagogic strategy is detachment. High school and university teachers can simply present the theory of evolution by natural selection, elucidating its conceptual complexity and demonstrating its enormous explanatory power. Detaching this presentation from religious issues avoids any kind of conflict with religious issues, eliminating the expenditure of emotional energy needed to deal with broader philosophical issues that science educators may be poorly equipped to address.

Detachment from religious issues may well be the best strategy for most science teachers, but it comes at a substantial intellectual cost. Perhaps the science educator could be satisfied with having students understand Darwin's theory, regardless of whether they actually believe it. But students are unlikely to expend the substantial effort required to overcome the conceptual difficulties that impede understanding if they are convinced that it is false (Sinatra et al. 2003). If such convictions arise because of coherence difficulties and emotional obstacles arising from students' common perceptions that Darwin conflicts with their theological beliefs and personal motivations, then the detachment strategy will have limited pedagogical effectiveness. The educational goal of getting students to appreciate the scientific value of the theory of evolution by natural selection would not be fully accomplishable using the detachment strategy. Moreover, detachment is no help in dealing with political attempts in some jurisdictions to require that creationism be taught in schools as an alternative to Darwin's theory.

So it might be better instead to address the perceived conflict between science and religion explicitly and attempt to remove it by one of various approaches. The postmodernist approach to reconciliation is highly relativist, asserting that there is no real competition between Darwinian and creationist accounts because they are just different ways of talking about the world, different language games, different modes of discourse. If science and religion are both just social constructions, they need not be understood as making different substantive claims about the origins of species, so there is no reason to see a conflict between them.

This view of science is held by many sociologists and historians of science, and has even been advocated by some science educators. However, there are good philosophical reasons for rejecting it (e.g. Thagard 1999; Brown 2001); and the postmodernist views of science and religion are unlikely to be accepted generally either by practicing scientists or religious leaders. Science purports to make claims about the universe, for example that it is about 13.7 billion years old, that life has been evolving on the planet Earth for more than 4 billion years, and that the human species is a result of this evolutionary process. There is substantial empirical evidence and theoretical basis for each of these claims, which markedly differentiates them from fictional modes of discourse such as Harry Potter novels. Hence the postmodernist, relativist approach to reconciling science and religion is unlikely to be intellectually effective. 
Another way of attempting to reconcile science and religion is to assign them to separate realms of concern, what Stephen Jay Gould (1999) called magisteria. On this view, science rules in the realm of fact and evidence, but religion has much to contribute to issues of morality and meaning. This view may be reassuring to some, but fails to deal with conflicts over specific claims such as how the human species came to be. Moreover, separatism with respect to realms does not address the crucial question of how religion could tell us much about morality and meaning if its fundamental assumptions, such as that the universe was created by a caring God, are false.

The currently most popular way of reconciling Darwinism and theology is sometimes called theistic evolution, which pushes the role of God back before the design of species to the creation of the universe (see e.g. http://www.theisticevolution.org/). On this view, God did not create individual species in the way that the Bible describes, but rather designed the universe in such a way that physical changes and biological evolution would eventually lead to the production of the human species. This reconciliation is currently favored by the Roman Catholic Church, mainstream Protestant denominations, and most forms of Judaism. Politically and psychologically, theistic evolution may be a good strategy for reassuring threatened students that Darwin is not incompatible with flexible forms of theology that do not require that the Bible be literally true.

There are two main drawbacks, however, to using the presentation of theistic evolution as a strategy for science education. First, it will not work for the fundamentalist students most in need of help with coherence difficulties and emotional obstacles to accepting Darwin. Such students will find theistic evolution almost as repugnant as Darwin's theory, because it violates their deep faith in the literal truth of their favorite religious texts and the ongoing intervention of God in human lives. Second, although theistic evolution avoids direct conflict with biological evolution, it still methodologically violates the general scientific approach of evaluating explanatory theories with respect to all the available evidence. There is no evidence that God created the universe originally, let alone that it was designed in such a way that after more than 13 billion years an intelligent species would emerge on the third planet of a minor star. Theistic evolution may not directly contradict biological evolution, but it clangs dramatically with the general scientific approach to understanding the origins of the universe, which can be addressed using the resources of physics (Steinhardt and Turok 2007).

If relativism and reconciliation fail, there remains the strategy of a more general confrontation between science and religion, subsuming the specific dispute between evolutionists and creationists. Polemicists such as Dawkins (2006) and Dennett (2006) have pursued such confrontation, arguing that there are scientific grounds for rejecting all the fundamental claims of religion such as the existence of God. If science supersedes religion in general, then there is no particular conflict between Darwin's theory of evolution and the cognitive claims and emotional offerings of theology. Religion is false, so it ought to pose no threat to scientific theories supported by evidence, including natural selection. Pursuing this line of argument, however, may be difficult in places where criticism of religion is politically or socially prohibited.

To be effective, the confrontation between science and religion needs to address cognitive and emotional issues that tend to be neglected by advocates of science. Cognitively, they tend to assume that the evidence-based methods of science supersede the faith-based thinking of religious people, but religionists reply that the preference for scientific evidence is just another kind of faith. Thagard (2010) argues that there are good reasons for preferring evidence over faith as a way of fixing beliefs. One major reason is that faith provides no way of adjudicating between competing claims such as whether the true 
divinity is the god of the Christian Bible or the myriad gods of the Hindu, Roman, and Greek traditions. In contrast, science proposes the procedure of evaluating competing explanatory hypotheses with respect to all the evidence, choosing the best. This procedure offers a way of settling intellectual disputes that is far more effective and far less rancorous than aggressive assertions about whose faith is superior. Moreover, scientific methods of figuring out how the world works have had amazing practical effects, seen in technologies such as lasers and computers. Hence science can legitimately be taken to supersede religion when cognitive conflicts about facts and theories occur.

What about emotional conflicts concerning values? When we discussed the emotional obstacles to accepting Darwin, we described the appealing package that comes with religion, including a caring God, immortality, free will, meaning and morality. Thagard (2010) argues at length that evidence or lack thereof requires abandoning the first three of these appealing ideas. Nevertheless, meaning and morality can survive in naturalistic forms consistent with human biology and psychology, without God, immortality, or free will. Thagard presents evidence for concluding that the meaning of life is love, work, and play, which together meet fundamental human psychological needs. Contrary to the widespread belief that morality requires religion, a moral system can also be developed by taking into account scientific evidence about psychological and biological needs. If these claims are correct, then at least some of the emotional appeal that leads to the rejection of Darwinian and scientific ideas can be countered by developing scientifically-informed philosophical views of meaning and morality, in the long tradition of naturalists such as Epicurus and John Stuart Mill.

We concede, however, that the confrontational strategy is not well suited to many educational situations. It is much more likely to be pedagogically effective in advanced university courses than in high school classes, especially ones occurring in bastions of religious fundamentalism such as Arkansas and Alberta. Confrontation may be politically difficult if it leads to major conflicts between teachers, students, and parents. It may not even be the psychologically most effective way of bringing about emotional conceptual change, for which more subtle methods of persuasion may be less likely to lead to disputants digging in and dogmatically asserting their positions. Much more research is needed into how belief revision and emotional change interact with each other.

We leave it to science educators to figure out which strategies for dealing with the cognitive and emotional conflicts between Darwinism and religion are most likely to be effective in their particular circumstances. There are solid intellectual grounds for rejecting the relativist and separatist approaches to reconciliation, but the theistic-evolution approach may be a useful transition to assisting students to see how science might proceed without generating a direct conflict between evolution and theology. Often, however, science educators will have to fall back on the local strategy of detaching science from religion, even if disputes on a broader level may require dealing with a confrontation between conflicting cognitive and emotional stances. Ironically, political attempts to keep creationism out of the schools may undermine cognitive strategies that help students appreciate the strengths of Darwinism by contrasting it with theological approaches.

Any effective strategy for science education should include a more sophisticated understanding of scientific methodology than is usually present in science courses. Science textbooks often begin with a simplistic view of scientific method as hypothesis testing: generate a hypothesis, design an experiment to test it, and reject the hypothesis if the experimental prediction is not observed. The methodology of Darwin and other scientists is much more complex, including processes such as dealing with experimental anomalies and evaluating theories by comparing them with competing theories. Thagard (2009) offers a 
concise introduction to issues in the philosophy of science relevant to controversies about evolution.

\section{Conclusion}

Darwin's theory of evolution by natural selection is one of the most important intellectual developments in human history. An understanding of it should be part of the mental equipment of science students and indeed of all educated people. Students ought to be taught to appreciate its power in explaining the origin and distribution of species, as well as in explaining many aspects of human existence such as the biological basis of our perceptual, emotional, and cognitive capabilities. Ideally, students should also acquire an appreciation of the limitations of Darwinian explanations, evident in overextensions to cultural phenomena proposed by some sociobiologists and evolutionary psychologists (Richardson 2007). Some of the feared consequences of Darwin's ideas, for example that people are genetically determined by their selfish genes towards greed, violence, and destruction, are based on misunderstandings of evolutionary theory. Natural selection can explain how desirable human characteristics such as altruism and empathy could have evolved through biological processes such as group selection and neural development (Sober and Wilson 1998; Thagard 2010).

We have reviewed what we see as the main cognitive and emotional obstacles to the more widespread acceptance of Darwinism. We hope that identifying them may help to develop more effective teaching strategies for overcoming resistance to the powerful scientific theory of evolution by natural selection.

Acknowledgments This research has been supported by the Natural Sciences and Engineering Research Council of Canada. We thank David Rudge, Kostas Kampourakis, and an anonymous referee for helpful comments.

\section{References}

Anderson, R. D. (2007). Teaching the theory of evolution in social, intellectual, and pedagogical context. Science Education 91, 664-677.

Blackwell, W. H., Powell, M. J., \& Dukes, G. H. (2003). The problem of student acceptance of evolution. Journal of Biological Education, 37, 58-67.

Breakenridge, R. (2008). What is it about evolution theory that Albertans don't get? Calgary Herald, from http://www.canada.com/calgaryherald/news/story.html?id=7cfcfff3-286a-4f29-9e81-e70951b54e4c. Accessed 13 Aug 2009.

Brem, S. K., Ranney, M., \& Schindel, J. (2003). Perceived consequences of evolution: College students perceive negative personal and social impact in evolutionary theory. Science Education 87, 181-206.

Brown, J. R. (2001). Who rules in science? An opinionated guide to the wars. Cambridge, MA: Harvard University Press.

Bunge, M. (2003). Emergence and convergence: Qualitative novelty and the unity of knowledge. Toronto: University of Toronto Press.

Chi, M. T. H. (2005). Commonsense conceptions of emergent processes: Why some misconceptions are robust. Journal of the Learning Sciences, 14, 161-199.

Chi, M. T. H. (2008). Three types of conceptual change: Belief revision, mental model transformation, and categorical shift. In S. Vosniadou (Ed.), International handbook of research in conceptual change (pp. 61-82). New York: Routledge.

Dawkins, R. (2006). The God delusion. New York: Houghton Mifflin.

Deniz, H., Donnelly, L. A., \& Yilmaz, I. (2008). Exploring the factors related to acceptance of evolutionary theory among Turkish preservice biology teachers: Toward a more informative conceptual ecology for biological evolution. Journal of Research in Science Teaching, 45, 420-443.

Dennett, D. (2006). Breaking the spell: Religion as a natural phenomenon. New York: Penguin. 
Evans, E. M. (2008). Conceptual change and evolutionary biology: A developmental analysis. In S. Vosniadou (Ed.), International handbook of research on conceptual change (pp. 263-294). New York: Routledge.

Gould, S. J. (1999). Rock of ages: Science and religion in the fullness of life. New York: Ballantine.

Hacking, I. (1975). The emergence of probability. Cambridge: Cambridge University Press.

Hokayem, H., \& BouJaoude, S. (2008). College students perceptions of the theory of evolution. Journal of Research in Science Teaching, 45, 395-419.

Kampourakis, K., \& Zogza, V. (2008). Students' intuitive explanations of the causes of homologies and adaptations. Science \& Education, 17, 27-47.

Kitcher, P. (1981). Explanatory unification. Philosophy of Science, 48, 507-531.

Kuhn, T. S. (1970). The structure of scientific revolutions (2nd ed.). Chicago: University of Chicago Press.

Kunda, Z. (1990). The case for motivated inference. Psychological Bulletin, 108, 480-498.

Kunda, Z. (1999). Social cognition: Making sense of people. Cambridge, MA: MIT Press.

Mayr, E. (1982). The growth of biological thought. Cambridge, MA: Harvard University Press.

Miller, J. D., Scott, E. C., \& Okamoto, S. (2006). Science communication. Public acceptance of evolution. Science, 313(5788), 765-766.

Popper, K. (1959). The logic of scientific discovery. London: Hutchinson.

Popper, K. (1978). Natural selection and the emergence of mind. Dialectica, 32, 339-355.

Preson, J., \& Epley, N. (2009). Science and God: An automatic opposition between ultimate explanations. Journal of Experimental Social Psychology, 45, 238-241.

Ranney, M., \& Thanukos, A. (2009). Accepting evolution or creation in people, critters, plants, and classrooms: The maelstrom of American cognition about biological change. In R. Taylor \& M. Ferrari (Eds.), Evolution, epistemology, and science education. Milton Park: Routledge (forthcoming).

Richardson, R. C. (2007). Evolutionary psychology as maladapted psychology. Cambridge, MA: MIT Press.

Schank, P., \& Ranney, M. (1992). Assessing explanatory coherence: A new method for integrating verbal data with models of on-line belief revision Proceedings of the fourteenth annual conference of the cognitive Science society (pp. 599-604). Hillsdale, NJ: Erlbaum.

Shtulman, A. (2006). Qualitative differences between naive and scientific theories of evolution. Cognitive Psychology, 52(2), 170-194.

Shtulman, A., \& Schulz, L. (2008). The relation between essentialist beliefs and evolutionary reasoning. Cognitive Science, 32, 1049-1062.

Sinatra, G. M., Southerland, S. A., McConaughy, F., \& Demastes, J. W. (2003). Intentions and beliefs in students understanding and acceptance of biological evolution. Journal of Research in Science Teaching, 40, 519-528.

Sober, E. (2008). Evidence and evolution: The logic behind the science. Cambridge: Cambridge University Press.

Sober, E., \& Wilson, D. S. (1998). Unto others: The evolution and psychology of unselfish behavior. Cambridge, MA: Harvard University Press.

Steinhardt, P. J., \& Turok, N. (2007). Endless universe: Beyond the big bang. New York: Doubleday.

Thagard, P. (1988). Computational philosophy of science. Cambridge, MA: MIT Press.

Thagard, P. (1992). Conceptual revolutions. Princeton: Princeton University Press.

Thagard, P. (1999). How scientists explain disease. Princeton: Princeton University Press.

Thagard, P. (2000). Coherence in thought and action. Cambridge, MA: MIT Press.

Thagard, P. (2003). Why wasn't O. J. convicted? Emotional coherence in legal inference. Cognition and Emotion, 17(36), 1-383.

Thagard, P. (2006). Hot thought: Mechanisms and applications of emotional cognition. Cambridge, MA: MIT Press.

Thagard, P. (2008). Conceptual change in the history of science: Life, mind, and disease. In S. Vosniadou (Ed.), International handbook of research on conceptual change (pp. 374-387). London: Routledge.

Thagard, P. (2009). Evolution, creation, and the philosophy of science. In R. Taylor \& M. Ferrari (Eds.), Evolution, epistemology, and science education. Milton Park: Routledge (forthcoming).

Thagard, P. (2010). The brain and the meaning of life. Princeton, NJ: Princeton University Press.

Thagard, P., \& Aubie, B. (2008). Emotional consciousness: A neural model of how cognitive appraisal and somatic perception interact to produce qualitative experience. Consciousness and Cognition, 17, 811834.

Thagard, P., \& Findlay, S. (2009). Changing minds about climate change: Belief revision, coherence, and emotion. In E. Olsson (Ed.), Science in flux: Belief revision in the context of scientific inquiry. Berlin: Springer (forthcoming). 